Fronteiras: Revista de História

Viver, sentir, esquecer: apostasia na trajetória de Rachel de Queiroz -

Plauto Daniel Santos Alves; Beatriz Rodrigues

\title{
VIVER, SENTIR, ESQUECER: \\ APOSTASIA NA TRAJETÓRIA DE RACHEL DE QUEIROZ
}

\author{
Plauto Daniel Santos Alves \\ Universidade Estadual do Ceará, Brasil \\ E-mail: plautosalves@gmail.com \\ Orcid: https://orcid.org/0000-0003-2953-8819 \\ Beatriz Rodrigues \\ Universidade Estadual de Maringá, Brasil \\ E-mail: bia sic@hotmail.com \\ ORCID: https://orcid.org/0000-0002-8784-0330
}

Data de recebimento: $11 / 06 / 2020$

Data de aprovação: 07/08/2020

DOI: https://doi.org/10.30612/frh.v22i40.13261

\begin{abstract}
Resumo: Esse artigo apresenta reflexões sobre as múltiplas identidades e versões de si que perpassam as narrativas da escritora Rachel de Queiroz. O enfoque recai sobre as redes de sociabilidades, os afetos e os sentimentos que transpassaram e emergiram no processo de sua cisão com o Partido Comunista. Para tanto, categorias próprias ao campo da História Intelectual (como o conceito de microclima) e aos estudos voltados à memória (como a noção de esquecimento) se fazem importantes. $O$ trabalho torna possível nuançar e perceber as tensões e silêncios que perpassam tanto a identidade pueril e jovial quanto a identidade mais intelectualizada e circunscrita à maturidade da escritora. Percebe-se que a ruptura de Rachel de Queiroz com as esquerdas não possui um marco definitivo, tratando-se de um processo paulatino e difuso ocorrido entre os anos de 1935 e 1940, marcado ora por aproximações, ora por distanciamentos e composto por uma intricada rede afetiva. Assim, as tramas históricas, políticas e literárias de Rachel de Queiroz compõem um cenário complexo para suas identidades, no qual estão entrelaçados os sentimentos, os afetos, os desejos, os medos, as dores, dentre outros elementos da sensibilidade da escritora.
\end{abstract}

Palavras-chave: identidade, memória, sociabilidade, intelectuais, Rachel de Queiroz

\section{VIVE, SIENTE, OLVIDE: APOSTASÍA EN LA TRAYECTORIA DE RACHEL DE QUEIROZ}

Resumen: Este artículo presenta reflexiones sobre las múltiples identidades y versiones del yo que impregnan las narrativas de la escritora Rachel de Queiroz. La atención se centra em las redes de sociabilidad, los afectos y sentimientos que han permeado y surgido en el proceso de su división con el Partido Comunista. Para esto, las categorías específicas del campo de la historia intelectual (como el concepto de microclima) y los estudios centrados en la memoria (como la noción de olvido) son importantes. El trabajo permite matizar y percibir las tensiones y los silencios que cruzan tanto la identidad infantil y juvenil, así como la identidad más intelectualizada y circunscrita de la madurez de la escritora. Se puede observar que la ruptura de Rachel de Queiroz con la izquierda no tiene una frontera definitiva, ya que es un 
proceso gradual y difuso que tuvo lugar entre los años 1935 y 1940, a veces marcado por aproximaciones, y en otras ocasiones por distanciamientos y compuesto por una intrincada red afectiva. De esta manera, las tramas históricas, políticas y literarias de Rachel de Queiroz componen un escenario complejo para sus identidades, en el que los sentimientos, afectos, deseos, miedos, dolores se entrelazan, entre otros elementos de la sensibilidad de la escritora.

Palabras clave: identidad, memoria, sociabilidad, intelectuales, Rachel de Queiroz

\title{
LIVE, FEEL, FORGET: APOSTASY IN THE TRAJECTORY OF RACHEL DE QUEIROZ
}

\begin{abstract}
This article presents some thoughts about the multiple identities and versions of herself that permeate the narratives of the writer Rachel de Queiroz. The focus is on the nets of sociabilities, the affections and the feelings that passed and emerged through the process of her split up with the Communist Party. There fore,specific categories of intellectual history's field (like the concept of microclimate) and the studies focused on the memory (like the notion of forgetting) are important. The research allows nuancing and perceiving the tensions and the silences that pervade both the puerile and youthful identity and the more intellectualized identity circumscribed to the author's maturity. It is clear that Rachel de Queiroz' rupture with the lefts does not have a definitive mark. It was a gradual and a diffuse process occurred between 1935 and 1940, sometimes marked by approximations, sometimes by distances and composed by an intricate affective network. Thus the historical, politic and literary plots of Rachel de Queiroz compose a complex scenario of her identities, in which the feelings, affections, desires, fears, pains, among others elements of the writer's sensitivity, are intertwined.
\end{abstract}

Keywords: identity, memory, sociability, intellectuals, Rachel de Queiroz

\section{Introdução}

Em função de seu sucesso retumbante, o romance de estreia de Rachel de Queiroz - $O$ Quinze (1930) - passou por diversas edições durante os anos. Sua versão original, entretanto, produzida em formato modesto por uma gráfica local, parecia (tal como tantas outras obras provincianas do período) fadada a obter fraca circulação e pouca atenção da crítica especializada. Não obstante, devido, em parte, a toda uma rede de contatos pessoais, o livro chegou a ser objeto de premiação no recém-criado certame da Fundação Graça Aranha e a angariar uma segunda publicação pela Editora Nacional (ACIOLI, 2003, p. 58-61), na qual consta a seguinte "nota introdutória":

O QUINZE é uma ousadia ingenua de ensaísta. Livro feito aos dezenove annos, ha de ter todos os defeitos daquillo que a gente produz nesta idade em que estou, quando não se tem a socegadaprudencia de ir devagar para fazer bem feito, quando nos governa a impaciência insoffrida de não esperar, de ver o nosso pensamento, mal é concebido, logo escripto, impresso, disseminado, cotejado com outros alheios, fazendo parte do patrimonio mental da 
humanidade... E' esta, pelo menos, a explicação que dou á arguição de não ter esperado mais tempo para fazer correr mundo o meu romance (QUEIROZ, 1932, p. 5).

O trecho acima permite entrever uma versão pueril e um tanto infantilizada produzida pela própria Rachel de Queiroz. Essa perspectiva da escritora geralmente vem atrelada ao "esquecimento" de uma série de competências que a tornavam mais apta ao traquejo com o universo intelectual do que os relatos levam a entender. No caso em questão, a autora teria deixado de mencionar uma obra poética anterior à publicação de seu primeiro romance e a breve, porém intensa experiência jornalística vivenciada no final dos anos 1920, marcos que lhe garantiram alguma noção das regras e da dinâmica vigente no campo editorial. (GUERRELUS, 2011, p. 77).

O Quinze carrega consigo inscrições culturais relevantes, tanto para a compreensão do percurso edificado em torno de Rachel de Queiroz, quanto para a literatura e a história brasileira de um modo geral. De todo modo, ele não constitui o enfoque deste trabalho, já que interessanos em particular a "nota introdutória" do romance devido ao modo como Rachel de Queiroz construiu uma imagem em torno de si marcada por uma credulidade excessiva que seria retomada anos mais tarde, em fins dos anos 1990 em uma coletânea de entrevistas - organizadas e, em parte, narradas pela irmã de Rachel de Queiroz - publicada à maneira de uma biografia (Tantos Anos, 1998). Assim como antes, decisões de juventude são caracterizadas como atos singelos e demasiado ingênuos e, embora dessa vez a situação trouxesse alguma dose de tensão - visto que são relatados os eventos que culminaram na primeira prisão da escritora e os procedimentos tomados por seu tio, o jurista Euzébio de Queiroz, para pô-la em liberdade - a cena toda é construída por meio de tons lúdicos, culminando com a própria Rachel de Queiroz, em uma caracterização de si jovial e inocente, se divertindo com o fato de que o leme do navio que a traz de volta à casa paterna lhe fora entregue pelo comandante da embarcação:

[...] Tio Eusébio me entregou ao Comandante Teixeira de Souza com uma carta do chefe de polícia do Rio, onde se ordenava que eu fosse entregue a meu pai, em Fortaleza. Tio Eusébio me deu um beijo, fez umas brincadeiras comigo - ele era realmente um homem maravilhoso. Muito inteligente, muito lúcido, um democrata autêntico: nos deixava discutir as maiores tolices, tolerava as nossas insolências comunistas e chegava a debater com a gente. Aquela cultura tão grande e nós uns bobalhões, mas ele discutia conosco de igual para igual; era mesmo um sujeito único.

O Comandante Teixeira de Souza me recebeu muito bem. [...] E viajavam no navio dois almirantes e um comandante [...]. Os quatro me adotaram e eu fiz uma viagem de princesa. [...] 
Quando íamos chegando a Natal, o comandante Teixeira de Souza me entregou a roda do leme e me deixou fazer toda a entrada do barco no porto. Ao lado, os meus ajudantes de ordens, os almirantes. Foi mesmo uma viagem muito divertida (QUEIROZ; QUEIROZ, 1998, p. 50-51).

Com efeito, esse tipo de caracterização da autora constitui tema recorrente nas elaborações em torno de sua figura. Uma de suas versões, talvez a mais difundida, remete à gênese d'O Quinze e aborda, sobretudo, seu caráter anedótico: o fato de que a obra, supostamente, fora concebida à luz de lampião, às escondidas do restante da família, por uma "menina" quase despossuída de autonomia e, sob diversos pontos de vista, bastante imatura (ACIOLI, 2003, p. 55-56).

Nesse sentido, partindo de um viés que acata a "multiplicidade desconcertante e cambiante de identidades possíveis" com as quais os sujeitos podem se alinhar "mesmo que temporariamente" (HALL, 2006, p.13), uma tessitura imbricada em contrastes e (in) completudes de significados torna possível pensar uma Rachel de Queiroz que, enquanto autora de si, delineia identidades embasadas em concepções de sua mocidade. Temática que constituiu objeto de discussões historiográficas anteriores (GUERRELUS, 2016a, 2016b), nas quais se enfocam as raízes políticas desse comportamento de forma a articular as constantes retomadas de suas próprias percepções de juventude com a guinada conservadora vivenciada pela escritora desde pelo menos o final da década de 1930. Nessa perspectiva, o elitismo presente em suas concepções do papel intelectual, sua declarada aversão ao varguismo e uma mudança radical na configuração de suas conexões afetivas funcionariam como espécie de chave explicativa para as dinâmicas que perpassam a escrita de si da romancista e a sua apostasia ante as posições políticas inclinadas à esquerda.

Sem nenhuma intenção de refutar a validade desses trabalhos, o que se objetiva aqui, balizado por esses estudos anteriores, é explorar novamente o papel das redes de sociabilidade na definição das identidades políticas da escritora, estabelecendo, no entanto, um enfoque mais detido sobre as afetividades, os sentimentos e os "silêncios" que transpassam suas relações. Pois, como afirma Jean François Sirinelli, embora "supervalorizar a importância dos arroubos emocionais" configure um "grave erro científico", essa "dimensão não deve ser por isso apagada" das análises. Pelo contrário, caberia atenção especial, como se objetiva nesse trabalho, aos "microclimas" que perpassam os laços de amizade dos atores sociais, visto que essa esfera, na qual "se interpenetram o afetivo e o ideológico" dá conta tanto da coesão política, como das sensibilidades vivenciadas por determinadas formas de coletividade (SIRINELLI, 2003, p. 250253). 
À vista disso, cabe retomar as reflexões de Jacy Alves Seixas para quem "as relações entre memória e história tem se dado excluindo, sistematicamente, a faceta involuntária e afetiva inerente" à primeira. Fato contraditório, uma vez que é essa dimensão que "parte das ciências humanas tem buscado precisamente integrar com o estudo dos mitos, das sensibilidades e paixões políticas". Nesse sentido,enfocar o"esquecimento" que, como visto, sefaz objeto integrante das narrativas de si que embasam as rememorações produzidas por Rachel de Queiroz, se torna uma opção pertinente, visto que, de outra maneira, esse permaneceria“"em uma espécie de limbo sombrio - frequentemente visto como ontologicamente inabordável, fora da linguagem e, portanto, da consciência e da cultura". Diante do ato de emudecer que marca a trajetória da escritora, o esquecimento emerge, pois, como "um percurso no tempo e no espaço que se expressa em linguagens e formas que participam, de maneira sutil ou escancarada, dos jogos de poder e submissão, dos contornos das socializações e, obviamente, da estruturação do eu.” (SEIXAS, 2013, p. 02)

\section{Divórcio e Apostasia}

Em Tantos Anos, a década de 1930 emerge como um ponto de inflexão na trajetória de Rachel de Queiroz uma vez que, segundo o relato em questão, foi durante aquele período que se definiu a identidade política (conservadora e inclinada à direita) cujos contornos caracterizariam a maturidade da escritora. Com efeito, esse marco parece interessante como ponto de partida, visto que não é preciso muita empatia para assumir que aqueles anos não foram fáceis para a jovem intelectual. De início, sua breve militância nas fileiras do Partido Comunista Brasileiro (PCB) encontrou um desfecho desagradável já em 1932, em meio a uma querela sobre o conteúdo de seu segundo livro, João Miguel (1932). É curioso salientar que, apesar da gravidade da situação, no que compete ao episódio, o que se encontra em Tantos Anos são cores inusitadas, ou até mesmo jocosas:

[...] uma pessoa da direção do Partido me procurou com um recado: eu deveria lhe entregar os originais do meu romance para que fossem lidos pelos dirigentes. [...]

Obedeci, de má vontade. [...]

[...] Levantei-me, devagar, do meu banco. Cheguei à mesa, estendi a mão e pedi os originais [...] olhei para trás e vi que estava aberta a porta do galpão, a sua única saída. E, em vez de voltar para o banco, cheguei até o meio da sala, virei-me para a mesa e disse em voz alta e calma: "Eu não reconheço nos companheiros condições literárias para opinarem sobre minha obra. Não vou fazer correção nenhuma. E passar bem!”. 
Voltei-me para a porta e meti o pé na carreira. Na verdade, eu estava morrendo de medo daquele local solitário, daqueles homens mal-encarados. Por sorte minha, no poste junto à calçada, um bonde tinha parado e ia dando partida. Atirei-me aos balaústres, subi no bonde já em movimento e me sentei no banco entre vitoriosa e apavorada. Desse dia em diante, nunca mais tive contato pessoal com os dirigentes do Partido (QUEIROZ; QUEIROZ, 1998, p. 39-41).

Embora a cena passe a ideia de ato abrupto, realizado no calor do momento, é possível conjecturar que a ruptura com a cúpula decisória do PCB também tenha envolvido alguma troca prévia de informações e breves debates informais com companheiros próximos em situação similar, uma vez que ela não se configurou como uma atitude individual, mas constituiu uma cisão partidária coletiva, praticada, na regra, por intelectuais descontentes. Nesse sentido, em entrevista concedida a uma comitiva da Câmara dos deputados pouco após a publicação de Tantos Anos, a autora fez menção a certa dualidade existente entre "comunistas dogmáticos" e "trotskistas intelectualizados", lançando mão, inclusive, de tons bastante dicotômicos:

O SR. ENTREVISTADOR (Tarcísio Holanda) - Como foi essa identidade intelectual que a senhora teve, naqueles tempos, com o trotskismo?

A SRA. RACHEL DE QUEIROZ - Eu era comunista, depois briguei com os comunistas. Descobri os trotskistas, porque os comunistas eram muito burros, muito certos, muito fechadinhos, muito apertadinhos, e os trotskistas tinham uma visão mais ampla. O Trotski que era o puxador da corrente. Era um homem de grande talento e escrevia muito bem. Dessa forma, passei muito cedo para os trotskistas. O resultado foi que, sendo de esquerda, de vez em quando me prendiam, mas eu não tinha nenhuma ligação com o Partido Comunista(Entrevista. Disponível em:https://www2.camara.leg.br/a-camara. Acesso em: 01 de junho de 2020).

Há muito que dizer sobre o ponto discutido acima. De início, cabe esclarecer que, a partir de 1929, uma maior ingerência do Komintern nas decisões internas do PCB deflagrou um processo político conhecido como "proletarização" cuja marca principal consistiu no afastamento dos quadros advindos da elite ou, detentores de privilégios sociais resultantes da acumulação de capital cultural, dos postos decisórios da organização, os quais passaram a ser ocupados por "legítimos" integrantes da classe trabalhadora (VIANNA In: FERREIRA; REIS, 2007). Entre os indivíduos classificados como "intelectuais", principais afetados pelas mudanças descritas, tais modificações dividiram opiniões e suscitaram diferentes tomadas de posição: houve os que se dispuseram a falsificar origens camponesas para justificar sua permanência em alguma posição dirigente; os que cederam às demandas partidárias, submetendo-se a morar em condições precárias e abdicar de vantagens sociais a fim de se depurar de suas nocivas influências burguesas, além, é claro, de resignarem-se a atividades de pouca relevância (RUBIM In: MORAES, 1998); e os que juntamente com Rachel de Queiroz, 


\section{Lívio Xavier e Mario Pedrosa aderiram à oposição trotskista (MARQUES NETO; KAREPOVS} In: RIDENTI; REIS FILHO, 2002).

Em Tantos Anos, também há notícia do descontentamento com as mudanças acontecidas no PCB durante a primeira fase da década de 1930. Nesse caso se salienta a ênfase que os dirigentes colocavam na "questão da disciplina" dos intelectuais, considerados por eles uma “espécie de subclasse pouco merecedora de confiança” (QUEIROZ; QUEIROZ, 1998, p. 39). Além disso, se percebe o grau de proximidade que Rachel de Queiroz manteve com revolucionários trotskistas, principalmente com Lívio Xavier, de quem foi vizinha quando habitou apartamento localizado na Rua do Carmo, em São Paulo:

Esse período em São Paulo foi o melhor do meu trotskismo. Era esse grupo de trotskistas a fina flor do movimento. A desgraça era que só tínhamos teóricos e não tínhamos massa. [...] os grupos paulistas com que tivemos contato nos receberam com o maior carinho; e em São Paulo, me senti muito feliz. Ensinava, dava aulas particulares à noite, no Sindicato de Professores de Ensino Livre, e traduzia para a Atena Editora. Tinha a minha filhinha e tomava conta dela o tempo todo.

[...] À volta, sob as garoas noturnas [...] vínhamos todos enroladinhos nos nossos capotes, todos salvando o mundo. E era no apartamento de Lívio, pegado ao meu, o quartel-general dos trotskistas (QUEIROZ; QUEIROZ, 1998, p. 64-65).

É curioso que a escritora demarque a forte presença de intelectuais no movimento trotskista, uma vez que essa característica era utilizada pelos militantes do PCB para deslegitimar as ações da corrente rival. Em realidade, havia entre os trotskistas uma base considerável formada pelos trabalhadores das gráficas (MARQUES NETO; KAREPOVS, In: FERREIRA; REIS FILHO, 2007, p. 395). Em todo caso, ao optar por essa corrente, tanto "intelectuais", como "operários", eram obrigados a lidar com certa dubiedade em relação à sua filiação partidária. Tópico um tanto quanto confuso e que, por isso mesmo, gerava desentendimentos até entre os contemporâneos da época, como se pode notar, mais uma vez, através dos relatos da escritora, que nos dão nota da indecisão de um inspetor de polícia quanto à ilegalidade do movimento:

[...] E veio um inspetor de polícia à nossa procura, creio que se chamava Waldemar. [...] O tal Waldemar veio nos prender porque éramos comunistas etc. Logo Lívio foi buscar números do $A$ Classe Operária, que era o órgão oficial do PC $[\ldots]$ onde se proclamavam nossas expulsões e onde éramos tratados como social-fascistas, policiais e outros insultos. O inspetor ficou muito impressionado e foi embora. Três meses depois ele voltou. E, de novo, Lívio disse: "[...] Já não expliquei para o senhor que somos inimigos dos comunistas, que eles nos denunciam?”. 
O inspetor retrucou: "Acontece que eu tive contato com outros comunistas e fiquei sabendo da verdade. Me explicaram que vocês são muito piores que eles, porque eles só querem fazer uma revolução única, e vocês querem fazer revolução todo o tempo, com esse negócio de 'revolução permanente'!" (QUEIROZ; QUEIROZ, 1998, p. 65-66).

É preciso considerar com cautela o aspecto cômico da narrativa a fim de refletir sobre as questões políticas que estão em cena. Em primeiro lugar, é pertinente esclarecer que há uma incongruência - a mesma com a qual o inspetor Waldemar supostamente se debateu durante meses - na posição dos trotskistas no que concerne a sua ligação com o PCB, uma vez que se concebiam como uma fração que, embora fosse abertamente dissidente em relação às linhas políticas do partido, ainda mantinha com ele alguma espécie de vínculo e, portanto, se dispunha a colaborar com seus integrantes, apesar de serem encarados, por esses últimos, como membros de uma organização autônoma, oposta e nociva cujos princípios e atividades deveriam ser combatidos (MARQUES NETO; KAREPOVS In: RIDENTI; REIS FILHO, 2002).

Em segundo lugar, a noção de "revolução permanente" só emergiu, enquanto elemento definidor do trotskismo brasileiro, em meio a uma série de desentendimentos que, da maneira que se encontram ordenados, buscam promover um clima burlesco. No que concerne à experiência de Rachel de Queiroz, a crença na continuidade do processo revolucionário russo como uma medida estratégica mais bem delineada que aquela advogada por Stalin, não aparece como um elemento importante no rol de questões que levam à opção pela corrente. Em vista disso e com base no que foi delineado até aqui, é possível levantar a hipótese de que a defesa de valores e de uma identidade intelectual plenamente conciliável com a militância pode ter sido, não somente para a escritora, mas também para uma considerável parcela dos ativistas trotskistas, uma motivação mais palpável, constituindo parte fundamental do "microclima" desse coletivo. De fato, como se pode perceber em carta trocada com Lívio Xavier, uma de suas lideranças mais notáveis, Mário Pedrosa, nutria bastante apreço por esses princípios:

Obedeci a ordem da Classe Operária. Fui procurar os homens. Encontrei o camarada Mario Grazini, secretário dos Gráficos. Conversei com ele. Quando soube que era intelectual e advogado ficou muito contente. [...] Quando deixei o, estava entusiasmado. Cantou-me para entregar-me à causa com devotamento e sacrifício. Senti um calafrio - lere fus du parvenir desapareceu como por encanto - tive saudades de tudo por antecipação. Ouvi o apelo sedutor da sociedade. Então, entrincheirei-me no ponto de vista da classe - e disse que, burguês intelectual, não devia ser militante, mas estaria à disposição para todas as tarefas intelectuais que me entregassem (KAREPOVS In PUCU; BÔAS \& PEDROSA, 2019, p. 55-56). 
Por último, salienta-se o tom alegre e otimista empregado pela autora para descrever seu breve período de engajamento entre os quadros trotskistas. Naturalmente, isso se deve em parte ao fato de que as expectativas em relação ao uso de suas capacidades físicas e mentais se encontravam de acordo com as atividades que a militância lhe ofertava, fosse ela a prática do magistério, a realização de traduções, ou mesmo a vida boêmia. No entanto, cabe ressaltar aqui que, no conjunto, o quadro formado por essas cenas contrasta vivamente com as cores utilizadas para descrever os primeiros anos de militância, nos quais se realizou a aproximação de Rachel de Queiroz com o Partido Comunista:

[...] Como em Fortaleza o grupo era muito pobre em pessoas de instrução melhor, operários na maioria [...] fiquei como uma espécie de consultora, por causa dos meus contatos no Rio. Inscrevi-me então como membro do Partido. Mas era tudo muito precário, naquela estreita clandestinidade. [...]

[...] Prestes era nosso ídolo e, em certo período, nosso elemento de contato com a União Soviética. Tudo que se recebia de lá vinha através do Uruguai e era então passado para o pessoal do Rio, que distribuía o material para nós, nos estados. E tudo muito mal traduzido do espanhol. Diziam 'campesinos' por camponeses, 'burguezitos' e coisas assim. [...]

Os dirigentes do Rio me fizeram então secretária da Região no Ceará. Não por mérito, mas por ser capaz de escrever e datilografar [...] (IDEM, p. 36).

No geral, tal imagem negativa configura o espelho invertido da experiência de militância trotskista. Composição que não desautoriza as impressões da autora sobre sua passagem pelo PCB, mas que também não pode ser tomada como absoluta, nem aceita de forma passiva uma vez que, conscientemente, ou não, acaba incidindo naquilo que BOURDIEU (2000) designa por meio da expressão "ilusão biográfica", ou seja, a tendência, apresentada por determinados tipos de relatos, à exclusão dos elementos contraditórios presentes nas trajetórias biográficas em função de um único princípio norteador. Nesse sentido, uma reflexão sobre o conceito e o papel desempenhado pelos intelectuais pode vir a ser pertinente para a compreensão de tais identidades assumidas pela autora.

\section{Polifonias Intelectuais}

O conceito de intelectual se encontra demarcado por uma vasta pluralidade de usos e modelos que, segundo Sirinelli, suscita questões sobre a "polimorfia" e sobre a "polifonia" dessa noção. A primeira expressão remete às mudanças quantitativas que pode sofrer o contingente de intelectuais de um meio qualquer em função da passagem do tempo e, sobretudo, ao fato de que essa apuração está sempre subjugada às mudanças na "acepção [...] da palavra". 
O que significa dizer que o número de sujeitos que se outorgam ou que podem ser assim nomeados varia não somente por conta das condições sociais (aumento ou diminuição do público leitor, o número de quadros universitários ou burocráticos, etc.), mas, também por causa das mudanças nas diferentes formas que o conceito toma. Por sua vez a ideia de "polifonia" implica de partida que as "representações do intelectual" são "secretadas pelo próprio meio", o que traz dificuldades, visto que essas definições são "dissonantes" entre si e tendem, portanto, a ser excludentes em relação aos grupos rivais. (SIRINELLI, Op. Cit. p. 242-243)

Ainda segundo Sirinelli, essas duas características provocam a variabilidade de formas, que motivam as principais dificuldades em se lidar analiticamente com o conceito. Esse autor soluciona o dilema criado pelas constatações acima através do que chama de "definição de geometria variável, mas baseada em invariantes". O que significa "partir" de uma "definição ampla" que engloba os "mediadores e os criadores culturais" para, em certos momentos, "fechar a lente" mediante o uso de uma definição mais estreita ligada à ideia de "engajamento". Procedimento, que, não obstante seja assaz interessante, parece ainda problemático. (SIRINELLI, Op. Cit. p. 242-243)

Cabe cautela, visto que, tal categoria pode colaborar para a consagração da perspectiva "engajada" e, portanto, para a manutenção de um "panteão" dos intelectuais que assim se portaram. Nesse sentido parece profícuo concordar com a historiadora Rebeca Gontijo, que advertiu para o fato de que "a história dos intelectuais tem suas lendas e seus heróis", os quais devem ser estudados como "formas de mistificação" capazes por sua vez de engendrar visões do processo histórico na forma, por exemplo, de uma "idade de ouro", ou, "através da utilização de modelos, repetições, clichês e estereótipos" (GONTIJO IN BICALHO; GOUVEA \& SOIHET, 2005. p. 27).

Tais questões tornam-se ainda mais pertinentes ao direcionar o foco das considerações ao universo brasileiro, uma vez que o próprio Sirinelli admite que "essa palavra, engajamento, é muito francesa"1 e, assim sendo, diz respeito a uma "peculiaridade" nacional. Isto não significa afirmar que o intelectual - ou ainda o "engajamento" - seja uma exclusividade da história daquele país, mas, antes defender, em concordância com o historiador chileno Carlos Altamirano, a necessidade de se "tomar precauções contra" as análises, "que dão por certo a universalidade" das "formas francesas de atividade política e intelectual”, ou, "em termos mais

\footnotetext{
${ }^{1}$ SIRINELLI, Jean François. Sem mocinhos nem bandidos: entrevista publicada em 1/03/2013.Revista de Historia.com.br. Concedida a Bruno Garcia.
} 
gerais", o "cuidado com certa perspectiva que só diz respeito à vida cultural ou à notoriedade das grandes metrópoles" (ALTAMIRANO, 2013, p. 53).

Assim, pode-se entender que uma Rachel de Queiroz estabelecida há muitos anos como figura importante no campo literário e identificada com um conjunto de ideias conservadoras, se insere nessa "polifonia" na medida em que sua imagem se relaciona de forma negativa em um relato de sua experiência com o Partido Comunista Brasileiro. De maneira que o quadro composto se opõe frontalmente à exclusão da arena decisória e ao uso apenas "ornamental" que essa organização mantinha na sua relação com os intelectuais (RUBIM, 1998, p. 435).

Tal caracterização negligencia o aspecto circunstancial e provisório das medidas de "proletarização" cuja efetividade arrefeceria na segunda metade da década de 1930; contrapõe à organização uma percepção positiva da militância trotskista; emudece sobre o processo de questionamento que levou à ruptura, não somente com o PCB, ou com o trotskismo, mas com a esquerda como um todo e no espaço da lacuna deixada por esse silêncio, compõe uma percepção romântica da juventude engajada na militância àquela época:

[...]A primeira vez em que o comunismo mostrou a cara na rua foi em 1935; mas, antes disso, descoberto qualquer movimento ilegal, a repressão era implacável. Talvez por isso mesmo nós víssemos na revolução um certo colorido romântico, o apelo, a fascinação do proibido. Na verdade, éramos os revolucionários mais ingênuos do mundo.

Estávamos dispostos a morrer, a matar, a aceitar todas as submissões. Quanto mais o Partido exigia mais a gente se submetia, mais se entregava. Tempos depois, o que nos encantou, a mim e ao Zé Auto, quando tivemos contato com os trotskistas, foi a sua liberdade de espírito, de pensar, de dizer as coisas.

É certo que havia então, na mocidade mais lida, mais intelectualizada, um sentimento, quase uma obrigação, de pertencer a algum movimento político: ser comunista, ou ser contra o comunismo, enfim, o engajamento numa ideologia [...] (IDEM, p. 74).

Por sua vez, essa percepção jovial de si convive com outra, madura, que passa a prezar pela seriedade e ponderação em seus julgamentos, os quais parecem agora, - como numa espécie de consolidação dos valores defendidos durante a experiência trotskista - norteados prioritariamente pela atividade intelectual. Tal identidade se delineia, por exemplo, no momento em que Rachel de Queiroz abre mão de uma carreira estável na firma de exportações G. Gradhvol et Fils e do casamento com seu primeiro marido:

[...] quando deixei o Ceará, em julho de 1939, a casa [G. Gradhvol et Fils] ainda estava muito bem. Eu é que tinha compreendido que não podia continuar ali, que o comércio não era mesmo minha carreira. E estava ganhando a mesma coisa que o governador do estado! Ganhava três contos de réis, um salário maravilhoso para aquele tempo. Mas já estava certa de que meu 
casamento chegara ao fim, e não queria fazer o processo de separação no Ceará, por causa da família. E, além disso, havia parentes de Zé Auto morando em Fortaleza, um irmão dele de quem eu era muito amiga. Seria tudo muito penoso (IDEM, p. 69).

Em meio à emergência dessa nova identidade, é possível perceber paulatinas modificações nos espaços de sociabilidade frequentados por essa versão de si da escritora. $\mathrm{O}$ que configura o distanciamento dos grupos de esquerda e o estabelecimento de afinidades com sujeitos dotados de grande capital cultural - e enfatizados pelo relato enquanto tais -, como Mário de Andrade, Manuel Bandeira e José Américo. Este último, autor de A Bagaceira (1928), era também político bastante influente na esfera nacional e, na narrativa, distingue-se sintomaticamente por prezar pela autonomia das questões literárias:

Acontecia assim, ao se encerrar o expediente, Zé Américo reunia um verdadeiro salão literário no seu gabinete [...]. [Nessas ocasiões] só se conversava literatura ou temas políticos ligados à literatura e alguma política social.

[...] Via-se bem que a política era sua segunda paixão, a primeira era a literatura, era o livro, eram os escritores, era conversar com os literatos. E as sessões da tarde, embora se dessem no ministério, eram exclusivamente literárias. Ele sentado à mesa, na cadeira de ministro, e a gente ao redor. [...]Mas havia liberdade de dizer as coisas, discutir fatos. Ele, contudo, não permitia comentários políticos. Dizia: "Não quero atrapalhar os nossos assuntos".

Me lembro de que uma vez apareceu lá Juarez Távora, muito entusiasmado, discutindo a situação do país; e todos nós nos calamos. Juarez perguntou: "O que há?" Demos um sorriso amarelo e acabou o Juarez indo embora porque ousara falar de política naquela hora sagrada (IDEM, p. 119).

Ademais, o foco passa a se voltar às competências artísticas, literárias e profissionais dos indivíduos. Como no caso abaixo, em que Rachel de Queiroz descreve as aptidões do jornalista Evandro Moreira Pequeno, colega da romancista que é abordado como indivíduo que põe suas necessidades intelectuais acima das outras:

[...] Evandro, que [...] era muito bom músico, tocava fagote [...] estava alistado na orquestra daquele húngaro, Shengar [...] que não aceitaria um fagotista que não fosse muito bom. Evandro não se gabava de nada. Mas estava ansiosíssimo esperando por seu fagote, que mandara comprar na Europa; afinal recebeu aviso do Collis Postaux de que o instrumento vinha a caminho. [...] E no dia do desembarque da [sua] mãe, vinda do Ceará, recebeu ele o aviso de que fosse buscar a encomenda [...] Como iria fazer? Receber a mãe ou o fagote? [...]

[...] Fizemos algumas traduções juntos. Ele era lingüista, mas não era escritor, não tinha a frase literária fácil. Então, a gente arranjava traduções, e fizemos várias, que eu assinava junto com ele, ou ele assinava só. [...] 
Evandro era poliglota, aprendia facilmente qualquer língua, e foi estudar russo [...]Deu-se ao luxo de comprar toda uma coleção de autores [...]

E então deu a polícia na casa dele e encontraram aquelas coleções de luxo de livros em russo: carregaram tudo. E o levaram preso também. Mas o maior desespero de Evandro não era a prisão, era ter perdido os livros [...] (QUEIROZ; QUEIROZ, 1998, p. 86).

Como se vê, seja indeciso entre a mãe e o instrumento musical, ou entre a própria liberdade pessoal e o carinho pelos livros, a figura de Evandro Pequeno aparece marcada por suas ambições intelectuais. De forma oposta, José Auto - o primeiro marido de Rachel de Queiroz cujas relações com a literata iniciaram ainda à época do período de engajamento no PCB e, portanto, durante a fase "imatura" da escritora - é representado como um poeta hesitante, inseguro quanto à qualidade de sua pena e indeciso quanto às possibilidades de carreira profissional:

\begin{abstract}
"Gostei muito, mas não bastante, dos versos do seu poeta." [...] acho que foi essa sentença de Mário [de Andrade] que parou com a poesia de Zé Auto, que, aliás, era respeitado nas rodas literárias do Recife, como poeta de importância. Tentei lhe esconder a carta, mas Zé Auto a descobriu, fechou-se e nunca mais fez poesia, a não ser ocasionalmente; deixou assim de ser o poeta que tinha sido até então. Desde esse dia, lá em Itabuna, quando leu a carta (que, creio, conservou por muito tempo), Zé Auto se irritava quando alguém o chamava de poeta [...] (QUEIROZ; QUEIROZ, 1998, p. 113).
\end{abstract}

Identidades não se delineiam apenas nos termos mais simples e nas definições mais convenientes que transpassam o ato de atribuir características a alguém. Uma versão de si emerge, aqui, por meio dos laços afetivos que se estabelecem com as pessoas. Nesse procedimento, ao atestar o caráter de seu cônjuge e, mais tarde, demarcar um distanciamento em relação a ele, é possível apontar tacitamente uma mudança, uma ruptura não somente com o "outro", mas consigo mesmo. Assim, uma identidade pautada na vivência intelectual cujas raízes estão fincadas nos valores político-sentimentais que caracterizavam tanto o "microclima" das sociabilidades trotskistas, quanto à sensibilidade ideológica das vivências com Mário de Andrade e José Américo, emerge sub-repticiamente, nas páginas de Tantos Anos.

De modo homólogo, a pretexto de tratar de José Olympio, editor cuja presença fora marcante na divulgação da “onda toda dos nordestinos” (QUEIROZ; QUEIROZ, 1998, p. 186), a escritora demarca os contornos afetivos dessa outra identidade, ao se deter um momento sobre as atribulações do seu divórcio e sobre as demandas estabelecidas por um novo relacionamento:

Na crise da minha separação de Zé Auto, José [Olympio] e Daniel [irmão de José Olympio] se envolveram muito, me davam todo o apoio, não admitiam 
críticas. Tornaram-se imediatamente amigos de Oyama assim que ele entrou em minha vida. Anos depois eu dizia, brincando, que eles eram muito mais amigos de Oyama do que meus. Oyama, que fizera debandar, implacavelmente, o meu grupo de amigos (que Alba chamava os meus 'pinóquios'), aceitou sem dificuldade a amizade de José e Daniel no mesmo grau de intimidade e confiança [...] (IDEM, 1998, p. 188).

Um marco na constituição das redes de sociabilidade e afeição da escritora fica perceptível, ainda que de forma tímida, nessa passagem. Pois, ao mesmo tempo em que se salienta a forja de novas afinidades interpessoais, se menciona brevemente a crise com os antigos colegas de militância e profissão. Em meio à transição, um elemento constrangedor, Oyama, o segundo marido da escritora, emerge como o catalisador de seu afastamento, aquele que com sua "mão forte" (IDEM p. 113-114.) consolidou a ruptura com suas antigas amizades. Fato esse que não passou totalmente despercebido, tendo sido assinalado, em outra situação, por Isabel Lustosa:

A separação do primeiro marido e a união com o médico Oyama Macedo, a partir de 1941, indicam que a passagem para uma posição mais à direita se deu naqueles cinco anos e teve como componente principal o verdadeiro ódio que Rachel tinha contra Getúlio Vargas. Ódio que, pelo que sugere sua narrativa, era partilhado pelo marido. Como esse é também o momento da virada de Carlos Lacerda da esquerda para a direita, é possível presumir que Rachel, Oyama e os amigos mais próximos sofreram influência direta de Lacerda [...] (LUSTOSA, 2014, n.p.).

A ênfase da historiadora na influência de Carlos Lacerda certamente é condizente com o processo que se está analisando. De fato, ela corrobora uma identidade de si sustentada pela própria Rachel de Queiroz que, dentro da narrativa de Tantos Anos, passa a se enquadrar cada vez mais no rótulo do "intelectual” por meio da inserção em círculos de convivência que estabeleciam como marca de distinção, o gosto por literatura e uma postura ambígua, ou distante, em relação aos temas políticos. Um caso sintomático nesse sentido é a descrição da rede de amizades que orbitava a pessoa de Mário de Andrade:

Quando chegamos ao Rio, em 1939, Mário era um dos poucos amigos que já tínhamos; Zé Auto o tratava com muita consideração, embora nunca tenha convivido com ele como convivi. Mário fazia parte da minha roda e Zé Auto não freqüentava a nossa roda de intelectuais. Tinha outros amigos, mas sempre que encontrava Mário tratava-o com grande cordialidade. Já nós - a minha roda - adorávamos Mário e ele nos dava confiança total. Adorava, por sua vez, ver-se cercado de gente moça - Rubem Braga, eu, Murilo Miranda, Moacir Werneck de Castro, Carlos Lacerda, com quem era muito ligado; Eneida às vezes, mas não muito. Mário não gostava de comunista profissional, não era ligado aos comunistas (QUEIROZ; QUEIROZ, 1998, p. 113). 
Não obstante, parece pertinente adicionar cores ao quadro complexo que levou Rachel de Queiroz à apostasia. Nesse sentido, determinadas tensões se destacam como fatores internamente relevantes à trajetória e à elaboração identitária da autora, tais como, certas práticas conservadoras e machistas, assinaladas anteriormente por outros estudos (LÔBO, 2017, p. 55), cujo teor excludente caracterizava de forma difusa, as sociabilidades do Partido Comunista Brasileiro. Desse modo, em certa passagem de Tantos Anos, na qual uma dissertação sobre outrem se transforma em um discurso sobre si, a escritora alude de modo oblíquo ao moralismo sexual que perpassava a experiência da militância:

Em Itabuna conheci também Lena Weber, uma moça judia suíça [...] me revelou alguns aspectos da vida européia que eu ignorava: ela era liberada sexualmente, tivera seus amores com vários rapazes; apaixonou-se então por um médico da Bahia e com ele teve um caso sério. Eu ficava assombrada com aquela liberdade porque, não só lá em casa, na minha família, como também dentro do Partido, dentro dos grupos de comunistas, havia um moralismo muito severo: confundir "questão social com questão sexual" como diziam eles, era pessimamente visto. O PC e seus simpatizantes funcionavam como uma seita puritana, onde não havia nenhuma liberdade sexual entre moças e rapazes (QUEIROZ, 1998, p. 57).

Num complexo jogo de espelhos em que diversos estratos das múltiplas identidades de Rachel de Queiroz interagem, emerge uma versão de si marcada ainda pela ingenuidade e o assombro frente às práticas embasadas em valores que prezam por uma condição mais autônoma para as mulheres. Princípios como esses, entretanto, não escapariam por muito tempo - se é que de fato ainda não constituíam parte ativa de sua experiência - da órbita das vivências da escritora, pois, nos anos seguintes, constituíram questões prementes em sua trajetória, marcada pelo divórcio do primeiro marido e pelo afastamento das esquerdas.

Conforme se assinalou anteriormente, a narrativa de Rachel de Queiroz sobre si está trespassada pelas posturas políticas que assumiu durante sua trajetória. No entanto, como se vem argumentando, tais tomadas de posição não se enraízam apenas em escolhas racionais pautadas por critérios ideológicos, mas, emergem imiscuídas em valores, sentimentos e relações afetivas. Tais elementos, muitas vezes perpassados pelo ressentimento, pela dor e pela culpa, nem sempre logram ser plenamente expostos, mesmo em narrativas especificamente voltadas para esse fim.

Nesse sentido, a fim de dar conta dos "esquecimentos" que perpassam as sensibilidades e afeições dessa trajetória, parece pertinente buscar compreendera apostasia da escritora também por meio de espaços distintos daqueles que Tantos Anos reserva(ram) para tanto. 
Assim, se opta por direcionar a lente analítica para temáticas cujos efeitos geralmente não costumam ser correlacionados ao destino político da escritora, tais como o término de seu primeiro casamento com o poeta alagoano, Zé Auto, e o falecimento precoce de sua única filha. Com efeito, é relevante destacar que esses assuntos somente são mencionados de forma muito breve. Nesse sentido, a cena que descreve a morte de "Clotildinha" emerge espremida em duas linhas - "E eis que uma febre alta, seguida de meningite, em vinte e quatro dias roubou minha filhinha, em fevereiro de 1935" (QUEIROZ; QUEIROZ, 1998, p. 68) - e do mesmo modo, as considerações sobre o divórcio não se prolongam: "Vim aqui para o Rio de Janeiro e em pouco a separação estava consumada e nos desquitamos. E então conheci Oyama.” (IDEM)

O que dizer do sofrimento alheio? Sobretudo quando esse sofrimento faz o indivíduo calar sobre a dor que manifesta e sobre as atitudes que, direta ou indiretamente, suscita. Nesses casos cabe lembrar que "a dor não é uma invariante, uma consequência inevitável de situações dadas; é um modo de ser no mundo que varia segundo os tempos e as circunstâncias" estando, pois, propensa a constrangimentos cuja pressão impele, não à exterioridade, mas à quietude e ao tabu. Em vista disso, cumpre ao historiador refletir não somente sobre as interdições que perpassam a biografia de Rachel de Queiroz, mas uma vez que ele é "o vigia dos interstícios por onde entra em cena a infelicidade dita ou sufocada", também sobre os gestos e alternativas encontradas para expressar esse silêncio (FARGE, 2011, p. 22).

\section{Conclusão}

No ano de 1934 uma manifestação antifascista realizada em São Paulo, organizada em conjunto pelo Partido Comunista e por militantes trotskistas propositadamente no mesmo lugar e horário que um ato liderado pela Ação Integralista Brasileira (AIB), resultou em confronto violento na Praça da Sé. A ocasião demarca a saída de alguns intelectuais do movimento trotskista em virtude da insatisfação gerada pelo acontecimento, dentre eles Rachel de Queiroz. Para a escritora em particular, esse momento se estabelece como uma baliza importante em seu processo paulatino de afastamento das esquerdas e na definição de uma identidade conservadora, porquanto, a partir de então, encontrava-se situada numa posição de isolamento bastante ímpar, agravada pela transferência de José Auto para Maceió e posteriormente, pela morte de sua filha (GUERRELUS, 2016b).

A ruptura de Rachel de Queiroz com as esquerdas não possui um marco definitivo, tratase de um processo paulatino e difuso ocorrido entre os anos de 1935 e 1940 . Cheio de pequenas 
idas e vindas e marcado ora por aproximações, ora por distanciamentos, tal cisão é composta por uma intricada rede afetiva, não se tratando de uma escolha totalmente racional, mas pautada em afinidades emocionais e em redes de sociabilidades que, à sua maneira, modificam o comportamento e os valores dos agentes.

Conforme assinalado por David Harlan, os caminhos abertos às escritas da história encontram veredas múltiplas e variáveis que se estabelecem cada vez mais por meio de diálogos com as questões do presente (HARLAN, 2000, p. 60-61). Na tangente dessas reflexões, é interessante lançar olhar sobre o lugar que a biografia de Rachel de Queiroz ocupa na constituição de uma cultura política conservadora relativamente recente cujas bases se estabelecem em fins da década de 1990.

Não se pode deixar de mencionar que a "volatilidade" que perpassa o escopo do conceito de cultura política the confere "uma plasticidade demasiado grande" a qual, na sua pluralidade pode reservar à categoria, "guardadas as proporções, a mesma desventura que o conceito de “mentalidades" (SIRINELLI, 2014, p. 15). Conforme assinala o historiador Rodrigo Patto Sá Motta, é necessário cautela ao operar com a expressão, pois, os conceitos são quase sempre polissêmicos, principalmente nas ciências humanas e sociais. (MOTTA, 2009, p. 14). De todo modo, o conceito de cultura política pode ser interessante para entender o caso em questão na medida em que entrelaça os sistemas de ideias políticas mais formais com outras dimensões da ação humana, como “os sentimentos (paixões, medo), a fidelidade à tradições (família, religião) e a adesão a valores (moral, honra, patriotismo)". Além disso, o "vasto patrimônio que conforma as culturas políticas depende, para sua formação, das ações de seus inspiradores originais e dos aderentes posteriores", os quais colaboram para a construção de "eventoschave", se articulando com esses à maneira de "mitos" ou de "heróis" (MOTTA, 2009, p. 23 e 29). Assim, numa relação contínua que não opõe práticas e representações, mas que as articula as tramas históricas, políticas e literárias relacionadas a Rachel de Queiroz compõem um cenário complexo de suas identidades e trajetórias.

As atuações políticas e sociais que são mais evidentes em Rachel de Queiroz, de fato dizem muito sobre a militância da intelectual. Ao lado dessa imagem conhecida e edificada, porém, existem outras possíveis que foram inquiridas e postas a falar neste artigo. Os textos, sobre si ou sobre outrem de Rachel de Queiroz, nos levam à um emaranhado de interpretações, algumas vezes díspares que, juntamente com as sensibilidades que permearam suas sociabilidades, rejeitam uma identidade simplista e absoluta e dão lugar a percepções plurais, abertas a uma gama variada de significações no passado e no presente. 


\section{Referências}

ACIOLI, Socorro. Rachel de Queiroz. Fundações Demócrito Rocha, 2003.

ALTAMIRANO, Carlos. Intelectuales: nacimiento y peripecia de un nombre. In: Nueva Sociedad. No 245, mayo-junio de 2013.

BICALHO, Maria Fernanda Baptista; GOUVÊA, Maria de Fátima Silva (org.). Culturas Políticas: ensaios de história cultural, história política e ensino de história. Rio de Janeiro: Maud, 2005.

CASTRO, Ricardo Figueiredo de. Os intelectuais trotskistas nos anos 30. In: REIS FILHO, Daniel Aarão. Intelectuais, História e Política: séculos XIX e XX. Rio de Janeiro, 7 Letras, 2000 .

CHAUÍ, Marilena. Intelectual Engajado: Uma figura em extinção?. In: NOVAES, Adauto (org). O silêncio dos intelectuais. São Paulo, Cia das Letras, 2006.

COUTINHO, Nelson. Gramsci no Brasil: recepção e usos. In: MORAES, João Quartim de (org.). História do Marxismo no Brasil. São Paulo: Editora Unicamp. 2007.

DARNTON, Robert. Os dentes falsos de George Washington. São Paulo, Cia das Letras, 2005.

DENIS, Benoit. Literatura e engajamento. Bauru, EDUSC, 2002.

FARGE, Arlette. Lugares para a história. Belo Horizonte, Autêntica, 2011.

GONTIJO, Rebeca. História, Cultura Política e Sociabilidade Intelectual. In: GOMES, Ângela de Castro. História, Historiografia e Cultura Política no Brasil: algumas reflexões. In: SOIHET, Rachel; BICALHO, Maria Fernanda Baptista; GOUVÊA, Maria de Fátima Silva (org.) Culturas Políticas: ensaios de história cultural, história política e ensino de história. Rio de Janeiro: Maud, 2005.

GUERELLUS, Natália de Santanna. Regra e Exceção: Rachel de Queiroz e o Campo Literário dos anos 1930. Rio de Janeiro: Editora 7letras, 2013.

GUERRELUS, Natália de Santanna. Como um Castelo de cartas: Culturas políticas brasileiras e a trajetória de Rachel de Queiroz. Tese (Doutorado em História). 2015. Programa de Pós-Graduação em História, Instituto de Ciências Humanas e Filosofia. Niterói. 388p.

GUERRELUS, Natália de Santanna. “A velha devorou a moça?”: Rachel de Queiroz de 1910 a 1964. In: Faces de Clio, Rio de Janeiro, vol. 2, n.4, jul/dez 2016a, p. 60-80.

GUERELLUS, Natália de Santanna. Rachel de Queiroz política: uma escrita entre direitas e esquerdas no Brasil (1910-1964). In: Caderno espaço Feminino, Uberlândia, v. 29, n. 1, jan/jun 2016b, p. 211-236.

HALL, Stuart. Identidade cultural na pós-modernidade. Rio de Janeiro: DP\&A, 2004.

HARLAN, David. A história intelectual e o retorno da literatura. In: RAGO, Margareth; GIMENEZ, Renato Aloizio de Oliveira (Orgs.). Narrar o passado, repensar a história. Campinas: Ed. da UNICAMP, 2000. p. 15-62.

KAREPOVS, Dainis; MARQUES NETO, José Castilho. O trotskismo e os trotskistas: os anos 1920 e 1930. In: FERREIRA, Jorge ; REIS, Daniel Aarão. (Org.). As esquerdas no Brasil. A 
formação das tradições, 1889-1945. 1ªed.Rio de Janeiro: Civilização Brasileira, 2007, v. 1, p. 379-406.

KAREPOVS, Dainis; MARQUES NETO, José Castilho. Os trotskistas brasileiros e suas organizações políticas (1930 - 1966). In: Marcelo Ridenti; Daniel Aarão Reis Filho. (Org.). História do marxismo no Brasil. Partidos e organizações dos anos 20 aos $60.1^{\text {a }}$ ed.Campinas: Editora da Unicamp, 2002, v. V, p. 103-155.

LÔBO, Daniella Ataíde. Militância feminina no PCB: memória, história e historiografia. Dissertação (Mestrado). Universidade Estadual do Sudoeste da Bahia, Programa de PósGraduação em Memória: Linguagem e Sociedade, Vitória da Conquista, 2017.

LUSTOSA, Isabel. Rachel e o golpe. Rio de Janeiro: Instituto Moreira Salles. Disponível em: http://em1964.com.br/rachel-e-o-golpe-por-isabel-lustosa. 2014. Acesso em: 01 de junho de 2020.

MORAES, M. L. Q. A solidão de Pagu. In: FERREIRA, Jorge; REIS, Daniel Aarão. (Org.). As esquerdas no Brasil. Rio de Janeiro: Editora Civilização Brasileira,

PÉCAUT, Daniel. Os intelectuais e a política no Brasil: Entre o povo e a nação. São Paulo, Ática, 1990.

PROCHASSON, Cristophe. O caso em todos os seus aspectos. In: RIOUX, Jean-Pierre e SIRINELLI, Jean-François. Para uma história cultural. Lisboa, Editora Estampa, 1998.

QUEIROZ, Rachel de \& QUEIROZ, Maria Luiza de[1998]. Tantos Anos. Rio de Janeiro: José Olympio, 2010.

RUBIM, A. A. C. Marxismo, Cultura e Intelectuais no Brasil. In: João Quartim de Moraes. (Org.). História do Marxismo no Brasil. Campinas: Editora da Unicamp, 1998, v. 3, p. 305 382 .

SARTRE, J.-P. Em defesa dos intelectuais. São Paulo: Ática, 1994.

SEIXAS, Jacy. Gestão do esquecimento e cultura política brasileira: a construção de um objeto sensível de pesquisa. In: XXVII Simpósio Nacional de História: conhecimento histórico e diálogo social, 2013, Natal. Anais Eletrônicos - XXVII Simpósio Nacional de História, 2013.

SIRINELLI, Jean-François. Os Intelectuais. In RÉMOND, René. (Org.). Para uma história política. Rio de Janeiro, FGV Editora, 2003.

SERRANO, Carlos. El nacimiento de los intelectuales: algunos replanteamientos. Madrid. Asociación de Historia Contemporánea Marcial Pons, Ediciones de Historia, S. A. 2000 .

SIRINELLI, Jean François. Sem mocinhos nem bandidos: entrevista publicada em 1/03/2013. Revista de Historia .com.br. Concedida a Bruno Garcia.

THOMPSON. E. P. Algumas observações sobre a classe e a falsa consciência. In: THOMPSON, E. P. Peculiaridades dos Ingleses e outros artigos. São Paulo, UNICAMP, 2001. 